\title{
Application of Equisetum hyemale in Constructed Wetland: Influence of Wastewater Dilution and Contact Time
}

\author{
Febri Eko Wahyudianto ${ }^{1 *}$, Nur Indradewi Oktavitri ${ }^{1}$, Sucipto Hariyanto ${ }^{2}$, \\ Dhila Nur Maulidia'
}

1 Study Program of Environmental Engineering, Faculty Science and Technology, Universitas Airlangga, Indonesia

2 Study Program of Biology, Faculty Science and Technology, Universitas Airlangga, Indonesia

* Corresponding author's e-mail: febri.eko.w@fst.unair.ac.id

\begin{abstract}
In the present study, the systematic approach to evaluate potency of Equisetum hyemale in constructed wetland, bio-degradation and adsorption of TSS, COD, phosphate, and LAS were described. The overall objective of the study was to determine the ability of Equisetum hyemale to remove pollutants in laundry waste water in several percentage of dilution and contact time. This research used 4 groups of Equisetum hyemale in each reactor. Equisetum hyemale was planted in the richest nutrient of soil. The laundry waste water was contacted in batch system. The Equisetum hyemale removed TSS, COD, Phosphate, LAS until 90\% in variation of waste water dilution after 2 days of contact. Equisetum hyemale showed best performance in $100 \%$ of laundry waste water. It was observed that 4 days of contact time were optimal for removing pollutants in laundry waste water. The Equisetum hyemale removed TSS, COD, Phosphate, LAS up to $90 \%$ in variation of contact time.
\end{abstract}

Keywords: xonstructed wetlands, Equisetum hyemale, batch system

\section{INTRODUCTION}

Wastewater is an environmental issue which has always been the focus of the environmental management. It could not be separated from the urban development which is rapidly increasing especially in the developing countries. Along with the increasing of population, unavoidable environmental consequences occur. One of the many threats for the environment is from the laundry activities, which could come from both domestic and commercial laundries. In general, the laundry procedure uses detergents as a material to clean clothes and fabrics. The procedures generate the wastewater which contains phosphate, surfactant, grease, total suspended solid, organic material contents [Sawadogo et al., 2014]. High concentration of nitrogen and phosphate parameters in the water source causes eutrophication and unwanted odor [Shao, et al., 2014]. The surfactant content can increase the bacteria population while linear alkyl benzene sulfonate (LAS) that is found in laundry waste water can become a carcinogenic substance [Sumisha et al., 2015].

The effort to decrease the laundry waste impact is by conducting the laundry wastewater treatment. The Laundry wastewater treatment methods that can be performed involve coagulation, flocculation, adsorption, filtration, oxidation, biological treatment [Sumisa et al., 2015; Kim et al., 2005]. One of the biological treatments that can be used for laundry wastewater treatment is constructed wetlands $(\mathrm{CWs})$. CWs is a treatment plant that has some benefits, including ease of application, low energy use, and low operational costs [Wu et al., 2015; Timotewos et al., 2017]. These factors show that CWs can be applied in densely populated and even in the developing areas.

The treatment process in CWs is not fixated only on biological treatment such as pollutant absorption by plants or microorganism. In CWs, other treatment processes occur as well, for example sedimentation, filtration, adsorption, precipi- 
tation [Wu et al., 2014; Wu et al., 2015]. These processes can increase the pollutant elimination that occurs in the CWs unit. The use of CWs for waste water treatment can be affected by a few factors, which include plants species, hydraulic retention time, medium type, temperature, dissolved oxygen, and loading rate [Gosh and Gopal, 2010; Meng et al., 2014; Liu et al., 2016].

On the basis of these factors, in this research the plant used for laundry wastewater treatment was Equisetum hymale which has the ability to grow fast and well (Australian Weed Management, 2003). Aside from that this research aimed at measuring the pollutant removal efficiency in laundry waste water with dilution and detention time in CWs unit.

\section{MATERIALS AND METHODS}

The laundry wastewater was collected from commercial laundry at J1. Sutorejo, Surabaya City, Indonesia. The volume of laundry wastewater was $20 \mathrm{~L}$. The characteristics of wastewater were described in Table 1.

The batch experiments reactors used $40 \mathrm{~L}$ pots with the length, width, and height of $80 \mathrm{~cm}$, $20 \mathrm{~cm}$, and $25 \mathrm{~cm}$ respectively. The composition of media in the reactor consisted of $3 \mathrm{~cm}$ gravel ( $\$ 20 \mathrm{~mm}), 3 \mathrm{~cm}$ sand $(\phi 0.4-2 \mathrm{~mm})$, and 15 $\mathrm{cm}$ of soil and 4 group of Equisetum hymale as shown in Figure 1. Each reactor had 4 variations with 2 replications.

The implementation of laundry wastewater treatment was conducted in $2+$ stage experiments. The first stage was treating the laundry waste water with dilution variation. The laundry wastewater was diluted with $100 \%, 80 \%, 60 \%, 40 \%$, and $20 \%$ concentration. The diluted wastewater then was inserted in CWs reactor by a batch system in 2 days of contact time and then the samples were collected to analyze the TSS, COD, phosphate, and LAS parameters. The results obtained from the first stage were subjected to ANOVA to determine the concentration that would be used in the second stage.

Table 1. Characteristic of Laundry Wastewater

\begin{tabular}{|c|c|c|}
\hline Parameter & Unit & Concentration \\
\hline TSS & $\mathrm{mg} / \mathrm{l}$ & 641.00 \\
\hline COD & $\mathrm{mg} / \mathrm{l}$ & 876.92 \\
\hline Phosphate & $\mathrm{mg} / \mathrm{l}$ & 10.42 \\
\hline MBAS & $\mathrm{mg} / \mathrm{l}$ & 47.54 \\
\hline
\end{tabular}

The implementation of the second stage was conducted with contact-time variation. Time contact was arranged as 1, 2, 3, 4, and 5 days. The laundry wastewater was inserted into CWs reactor correspond to the variation planned by the batch system. The samples were collected corresponding to the detention time variation and were analyzed for the TSS, COD, phosphate and anionic surfactant parameters value. The results obtained from the parameters analysis were subjected to ANOVA to find the optimum time in laundry wastewater treatment by CWs.

The water quality analysis was conducted for the TSS, COD, Phosphate, LAS parameters. Each parameter was analyzed corresponding to the following procedures [APHA, 2005]:

- Gravimetric analysis - to determine the TSS value, dried at $103-105^{\circ} \mathrm{C}(2540 \mathrm{D})$,

- Titrimetric analysis with closed reflux - to determine the COD value (5220 C),

- Stannous Chloride analysis - to determine the phosphate value (4500-P D),

- Anionic surfactant as MBAS - to determine the LAS value (5540 C).

The calculation of the pollutant removal efficiency was conducted by comparing the initial concentration value $\left(\mathrm{C}_{\mathrm{d}}\right)$ and final concentration $\left(\mathrm{C}_{\mathrm{o}}\right)$ corresponding to the following equation [Dębska et al., 2015]:

$$
\text { \%removal }=\left(1-\frac{C o}{C d}\right) \times 100 \%
$$

\section{RESULT AND DISCUSSION}

\section{Influence of waste water dilution}

The results of removal efficiency for TSS, COD, phosphate and LAS parameters using Equisetum hymale with wastewater variation in CWs were presented in Figure 2. These results showed that the TSS removal efficiency was between 34-93\%. COD was between 74-95\%, phosphate was between 29-90\%, and LAS was between $95-99 \%$. The results proved the ideal performance of CWs unit.

The TSS removal efficiency in the CWs using Equisetum hymale ranged between 34-93\%. The highest TSS removal was shown with $80 \%$ wastewater dilution with the removal efficiency up to $93 \%$. That result correlated with the prior research, where the TSS removal using CWs to 


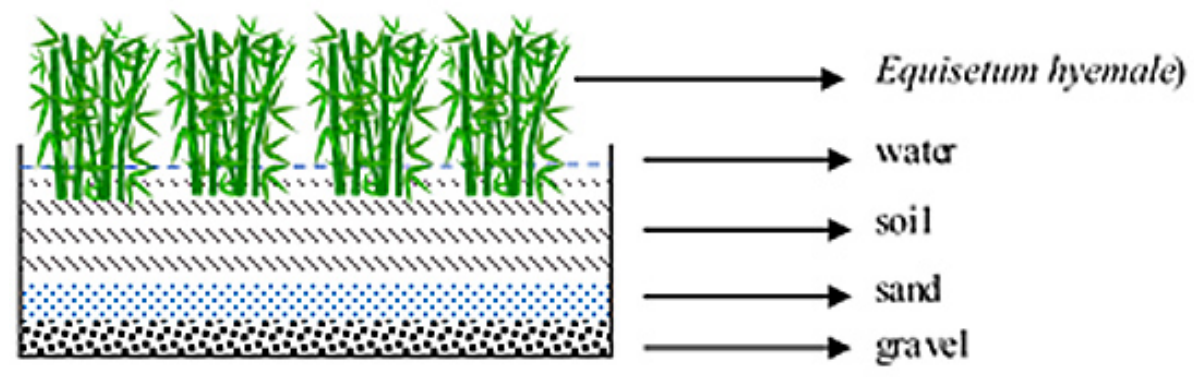

Figure 1. Schematic of reactor

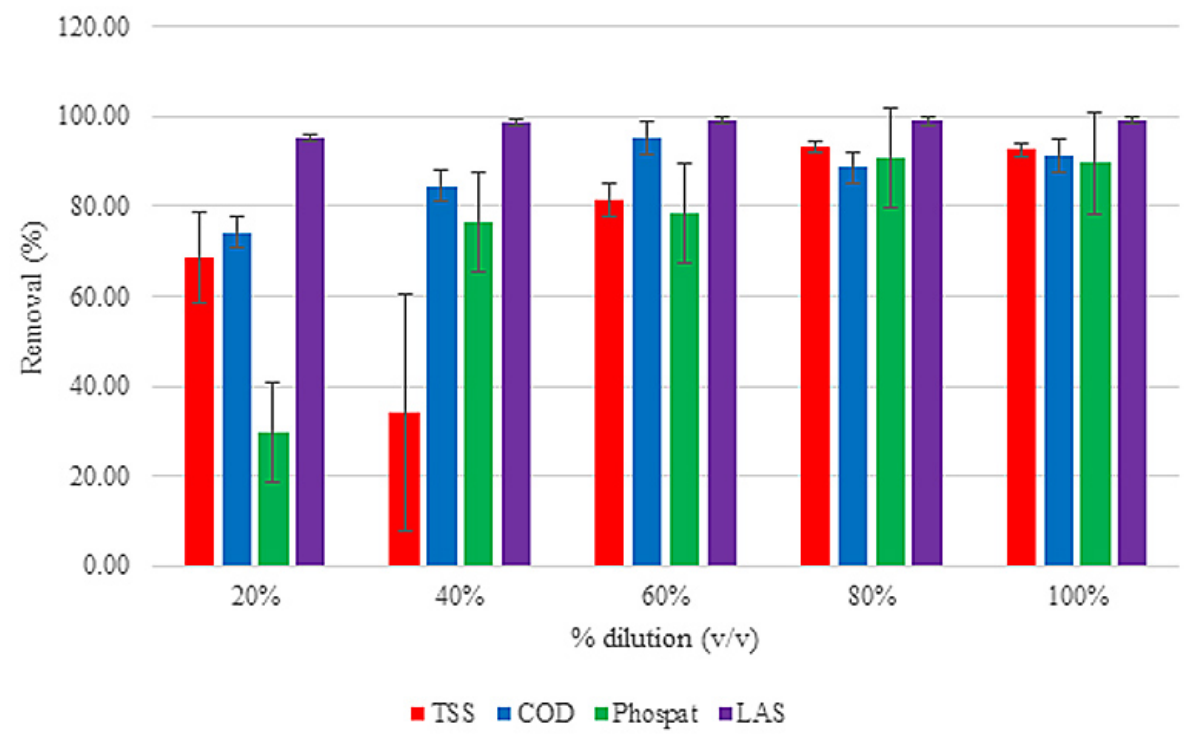

Figure 2. Effect of Dilution on the Efficiency TSS, COD, Phospates and LAS removal in CWs

treat laundry wastewater was up to $83 \%$ [Davison et al., 2005], while in Abdel-Shafy [2009] research for treating grey water could reduce the TSS concentration up to $94 \%$. The CWs using Equisetum hymale for TSS removal occurred because the solid particles were trapped into the media, which are soil, sand, and gravels.

The COD removal efficiency in the CWs unit using Equisetum hymale ranged between of 74-95\%. The highest COD removal was shown with $60 \%$ wastewater dilution with the removal efficiency up to $95 \%$, which has no significant change with $100 \%$ wastewater dilution. The research by Puchlik [2016] showed that with CWs unit, it could reduce the COD up to $79.3 \%$ by using common reed (Pragmites australis), while in the Dębska et al. [2015] research, the domestic wastewater treatment using $\mathrm{CWs}$ unit could reduce the COD value by up to $94 \%$. The result of laundry wastewater treatment using CWs with $E q$ uisetum hymale had a little bit higher of removal value than the previous similar studies. The COD removal in CWs happened because of the soil, sand, and gravel media which caused a filtration mechanism to remove organic matter. Apart from that the media could produce a bio-film which could increase the removal of organic matters.

The phosphate removal in the CWs using Equisetum hymale with variation of wastewater dilution ranged between $30-91 \%$, where the phosphate content value was up to 1.14-10.7 $\mathrm{mg} / \mathrm{l}$. The highest phosphate removal was shown with $80 \%$ wastewater dilution. The removal efficiency result in CWs with Equisetum hymale showed a quite high efficiency compared with Dębska et al. [2015] research where they used common reed, where the result obtained was up to $86.1-88.4 \%$. The phosphate removal process in CWs happened because of the media adsorption, sedimentation of microorganism activities, and the uptake process by the plants [Luca et al., 2017; Prodanovic et al., 2017].

The Linear Alkyl Sulfonate (LAS) removal in the CWs with Equisetum hymale was between 95-99\%. The highest removal was shown at $100 \%$ concentration of wastewater, where LAS 
concentration was $16.96 \mathrm{mg} / \mathrm{l}$. These results showed that Equisetum hymale could treat the laundry wastewater directly without dilution. The treatment using CWs with Equisetum hymale has higher capability of LAS removal efficiency than exhibited in Pucci et al., [2010] research, where they used Phragmites australis and the result obtained was only up to $84 \%$.

On the basis of the efficiency results obtained from TSS, COD, phosphate, and LAS parameters, it could be found that a CWs unit using Equisetum hymale has the capability of treating the laundry wastewater with the $100 \%$ concentration of waste compounds.

\section{Influence of detention time}

This research also was conducted to find the influence of detention time on the removal efficiency of TSS, COD, phosphate, and LAS parameters in the CWs using Equisetum hymale. The influence of detention time was conducted with variation of the detention time, which were $1,2,3,4$, and 5 days, respectively. The results from the laundry wastewater treatment using the CWs with Equisetum hymale by the detention time variation were expressed in Figure 3 . The results showed the the removal of TSS parameter ranged between $2.88-12.5 \%$, COD ranged between 53.57-95.12\%, phosphate between 95.49-99.32\%, and LAS between 99.16-99.76\%.

The highest TSS removal by the influence of detention time variable was $12.5 \%$ which was obtained in 3 days of detention time. Suspended particles could be removed by the media in CWs using Equisetum hymale plants, which were sand and soil. It was caused by the media, which was one of the important parts as filter.

The COD removal in a CWs using Equisetum hymale with variation of detention time had the highest efficiency in 4 days of detention time, reaching $85.12 \%$. The removal of organic matter such as COD in a CWs system could be caused by the filtration mechanism on the media's surface and the microbiology activities which resided in the media [Qin and Chen, 2016]. In Sultana et al., [2015] research it was shown that in 1 day detention time, it could reduce the COD value by up to $91 \%$. Meanwhile, in Merino-Solís et al., [2016] research, they showed that the COD removal efficiency was up to $32 \%$ with 2 days of detention time.

The phosphate removal in a CWs unit using Equisetum hymale with variation of detention time showed a very high removal efficiency, which was up to $95.49-99.32 \%$ and the highest removal was in 4 days of detention time. Detention time has influence on the removal process, which was caused by a few removal mechanisms ofCWs. The phosphate removal mechanism could be caused by the media's adsorption, sedimentation, the uptake process by the plants, and microorganism activities, which all were the processes that occurred for the phosphate removal in a CWs unit [Luca et. al., 2017; Prodanovic et. al., 2017].

The LAS removal efficiency obtained in CWs using Equisetum hymale with variation of detention time was $99.16-99.76 \%$. This result showed a very high level of removal. Each variation has the efficiency value that was relatively equal amounting to $99 \%$. This showed that the LAS removal process was optimal in this research. The highest removal was up to $99.76 \%$ which occurred in a

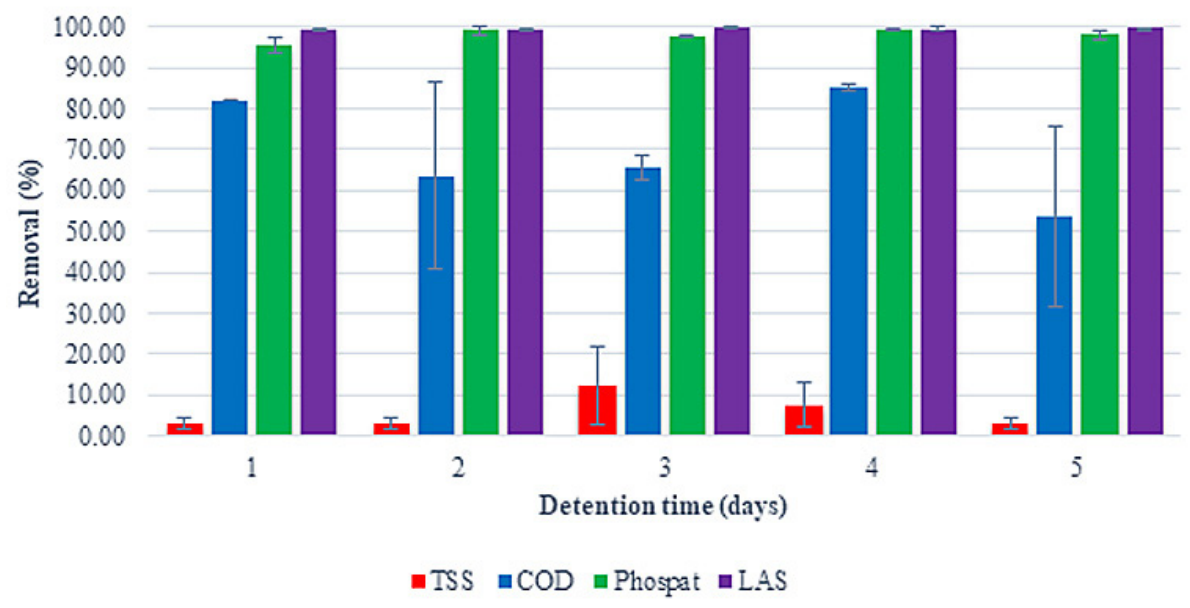

Figure 3. Effect of Detention Time on Efficiency of TSS, COD, Phosphate and LAS removal in CWs 
CWs with 5 days detention time. In the research by Thomas et al., [2017], it was mentioned that plants utilization in wastewater treatment could increase the removal efficiency of a CWs unit.

The laundry wastewater treatment with CWs using Equisetum hymale had optimal value in 4 days of detention time. This result was based on the efficiency analysis of TSS, COD, phosphate, and LAS parameters.

\section{CONCLUSION}

The Equisetum hyemale removed TSS, COD, Phosphate, LAS until $90 \%$ in variation of wastewater dilution after 2 days of contact. Equisetum hyemale showed the best performance in 100\% of laundry waste water. The optimal contact time for removal of pollutants in laundry wastewater was 4-5 days. The Equisetum hyemale removed TSS, COD, Phosphate, LAS up to $90 \%$ in variation of contact time.

\section{Acknowledgements}

This study was supported by Faculty of Science and Technology, Universitas Airlangga 2017 (SP POPA 628/UN3.6/KU/2016).

\section{REFERENCES}

1. Abdel-Shafy, H. I., El-Khateeb, M. Regelsberger, El-Sheikh, R., Shehata, M., 2009. Integrated Systemfor the Treatment of Blackwater and Greywater via UASB and Constructed Wetland in Egypt. Desalination and Water Treatment, 8(1-3), 272-278.

2. APHA, 2005. Standart Methods for The Examination of Water \& Wastewater. American Public Health Association.

3. Davison, L., Headly, T., Pratt, K. 2005. Aspect of Design, Structure, Performance and Operation of reed beds - eight year experience in Northeastern New South Wales, Australia, Water Science Technology, 51(10), 129-138.

4. Jóźwiakowski K., Bugajski P., Kurek K., de Carvalho M., Almeida M.A., Gajewska M., Siwiec T., Borowski G., Czekała W., Dach J., Gajewska M. 2018. The efficiency and technological reliability of biogenic compounds removal during long-term operation of a one-stage subsurface horizontal flow constructed wetland. Separation and Purification Technology, vol. 202, 216-226.

5. Gosh, D., Gopal, B., 2010. Effect of Hydraulic
Retention Time on the Treatment of Secondary Effluent in a Subsurface Flow Constructed Wetland. Ecological Engineering, 36(8), 1044-1051.

6. Kim, T. H., Park, C., Kim, S., 2005. Water Recycling from Desalination and Purification Process of Reactve Dye Manufacturing Industry by Combined Membran Filtration. Journal of Cleaner Production, 13(8), 779-786.

7. Luca, G.A.D., Maine, M.A., Mufarregem M.M., Hadad, H.R., Pedro, M.C., Sánchez, G.C., Caffaratti, S.E., 2017. Phosporus distribution pattern in sediments of natural and constructed wetlands. Ecological Engineering, 108, 227-233.

8. Liu, H., Hu, Z., Zhang, J., Ngo, H.H., Guo, W., Liang, S., Fan, J., Lu, S., Wu, H., 2016. Optimization on Supply and Distribution of Dissolved Oxygen in Constructed Wetlands: A Review. Bioresource Technology, 214, 797-805.

9. Merino-Solís, M.L., Villegas, E., Anda, J., LópezLópez, A., 2015. The Effect of the Hydraulic Retention Time on the Performance of an Ecological Wastewater Treatment System: An Anaerobic Filter with a Constructed Wetland. Water, 7, 1149-1163.

10. Meng, P., Pei, H., Hu, W., Shao, Y., Li, Z., 2014. How to Increase Microbial Degradation in Constructed Wetlands: Influencing Factor and Improvement Measures. Bioresource Technology, 157, 316-326.

11. Prodanovic, V., Hatt, B., McCarthy, D., Zhang, K., Deletic, A., 2017. Green walls for greywater reuse: Understanding the le of media on pollutant removal. Ecological Engineering, 102, 625-635.

12. Puchlik, M., 2016. Application of Constructed Wetlands for Treatment of Wastewater form Fruit and Vegetable Industry. Journal of Ecological Engineering, 17(1), 131-135.

13. Qin, R., Chen, H,. The Procession of Constructed Wetland Removal Mechanism of Pollutants. 4th International Conference on Mechanical Materials and Manufacturing Engineering (MMME 2016), Atlantis Press, 568-570.

14. Sawadogo, B., Sou, M., Hijikata, N., Sangare, D., Maiga, A. H., dan Funamizu, N., 2014. Effect of Detergents from Greywater on Irrigated Plants: Case of Okra (Abelmoschus esculentus) and Lettuce (Lactuca sativa) Journal of Arid Land Studies, 24(1), 117-120.

15. Shao, Y., Pei, H., Hu, W., Chanway, C. P., Meng, P., Ji, Y., dan Li, Z., 2014. Bioaugmentation In Lab Scale Constructed Wetland Microcosms For Treating Polluted River Water And Domestic Wastewater In Northern China. Journal International Biodeterioration \& Biodegradation, 95(A), 151-159.

16. Sultana, M., Mourti, C., Tatoulis, T., Akratos, C. S., 2015. Effect of Hydraulic Retention Time, Temperature, and Organic Load on a Horizontal Subsur- 
face Flow Constructed Wetland Treating Cheese Whey Wastewater. Journal of Chemical Technology and Biotechnolog, 91(3),726-732.

17. Sumisha, A., Arthanareeswaran, G., Thuyavan, Y. L., Ismail, A. F., Chakraborty, S., 2015. Treatment of Laundry Wastewater Using Polyethersulfone/ Polyvinylpyrollidone Ultrafiltration Membranes. Ecotoxicology and Environmental Safety, 121(2015), 174-179.

18. Thomas, R., Gough, R., Freeman, C., 2017. Linear Alkylbenzene Sulfonat (LAS) Removal in Constructed Wetlands: The Role of Plants in the Treatment of a Typical Pharamaceutical and Personal Care Product. Ecological Engineering, 106(2017), 415-422.
19. Timotewos, M.T., Kassa, K., Reddythota, D., 2017. Selection of Mesocosm to Remove Nutrients with Consructed Wetlands. Journal of Ecological Engineering, 18(4), 42-51.

20. Wu, S., Kuschk, P., Brix, H., Vymazal, J., Dong, R., Development of Constructed Wetlands in Performance Intensification for Wastewater Treatment: A Nitrogen and Organic Matter Targeted Review. Water Research, 57(2014), 40-55.

21. Wu, H., Zhang, J., Huu, H. Ngo., Wenshan, G., Hu, Z., Liang, S., Fan, J., Liu, H., 2015. A Review on the Sustainability of Constructed Wetlands for Wastewater Treatment: Design and Operation. Bioresource Technology, 175(2015), 594-601. 